\title{
PATTERN OF SKIN DISEASES IN PATIENTS VISITING UNIVERSAL COLLEGE OF MEDICAL SCIENCES- TEACHING HOSPITAL (UCMS-TH) FROM THE THREE DISTRICTS OF TERAI REGION IN NEPAL
}

\author{
Poudyal $\mathrm{Y}^{1}$, Rajbhandari $\mathrm{SL}^{2}$
}

\section{ABSTRACT}

INRODUCTION: The pattern of skin disease varies from country to country and in various regions within same country due to differences in socioeconomic and geographic factors. This study aimed to determine the pattern of skin disease from the three districts of Terai region in Nepal.

MATERIALAND METHODS: This was retrospective study done from the hospital OPD patient's record of Universal college of Medical Sciences \& Teaching Hospital (UCMS-TH), from $1^{\text {st }}$ September 2011 to $31^{\text {st }}$ August 2012. Patients from Rupandehi, Nawalparasi and Kapilvastu districts were taken. The diagnosis were entered in 15 categories like Acne, Alopecia Areata, Dermatophytosis, Drug reaction, Eczema, Leprosy, Lichen Planus, Melasma, Psoriasis, Pyoderma, Scabies, sexually transmitted diseses (STI), Urticaria, Viral infection and Vitiligo. Any diagnosis not in these categories, was kept at "Other" category. Monthly trend of disease was also analysed.

RESULT: Total number of patients from Rupandehi, Kapilvastu and Nawalparasi districts were 12446 (89.3\%), 661 (4.7\%), 836 (6\%) respectively. Dermatophytosis was the commonest 2003 (16.1\%) in Rupandehi district, it was second in number in Nawalparasi and Kapilvastu. Eczema was the commonest in Kapilvastu and Nawalparasi district with 103 $(15.6 \%)$ and $136(16.3 \%)$ respectively. Eczema was second in number in Rupandehi district. Acne was third in number in Rupandehi and Nawalparasi but vitiligo was third common dermatosis recorded in Kapilvastu district.

CONCLUSION: Dermatophytosis and Eczema are the most common dermatologic disorders in Terai region.

KEY WORDS: Terai, Eczema, Dermatophytosis

1. Assistant Professor, Department of Dermatology, Universal college of Medical Sciences \& Teaching Hospital, Bhairahawa, Nepal

2. Professor, Department of Dermatology, Universal college of Medical Sciences \& Teaching Hospital, Bhairahawa, Nepal

\author{
For Correspondence \\ Dr. Yogesh Poudyal \\ Assistant Professor, \\ Department of Dermatology \\ Universal College of Medical Science \& Teaching Hospital, \\ Bhairahawa, Nepal \\ E-mail:neverland791@yahoo.com
}




\section{INTRODUCTION}

Dermatological conditions account for a significant proportion of the global burden of disease in low and middle income countries.' Skin diseases are one of the leading cause of morbidity in Nepal. In 2010/2011 the skin diseases (Impetigo, Boils, Furunculosis) were seventh among the top ten causes of outpatient morbidity. ${ }^{2}$

The skin disease pattern in population is generally determined by different ecological factors like environment, economy, literacy and social custom. The pattern also varies from country to country and in various regions within same country. ${ }^{3}$

Nepal has three distinct ecological region. Mountain, hill and terai; pattern and prevalence of skin disease may vary according to the ecological region. The study done in population of hilly area showed eczema as commonest skin disease followed by pigmentary disorder and acne. ${ }^{4}$ Another study in hilly region showed papulosquamous disease to be commonest. ${ }^{5}$ The study done from the population in terai showed dermatophyte infection to be commonest. ${ }^{6}$ Studies done in India from two different ecological region showed different pattern of dermatological diseases. ${ }^{1,7}$

Studying the pattern of disease has importance in building healthcare strategies according to the requirement of population in specific area. Thus, the objective of this study is to analyze the pattern of dermatological disease in three districts of Terai region in Nepal.

\section{MATERIALAND METHODS}

This was retrospective study done from the hospital record of UCMS-TH. UCMS-TH is tertiary hospital situated in Rupandehi district, Nepal. The majority of the patients visiting in this hospital are from Rupandehi district. The patients from Nawalparasi, Kapilvastu, Palpa, Gulmi, Arghakhanchi, Pyuthan, Rolpa, Syangja districts and from the cities and villages close to border area of Rupandehi district also get service from this hospital.

Rupandehi, Kapilvastu and Nawalparasi are districts in Terai region of Nepal. Most of the land in these three districts is occupied by lowland plain and situated within an altitude between 67 to 300 meter. Tropical and subtropical climate is found in these three districts.
Department of dermatology maintains the record of all the patients visiting at OPD, in record book. The patients name, age, sex, address, diagnosis and treatment are recorded. The data used for this study was taken from this record. All the new and old cases were taken for study. All the diagnosis was made by dermatologist only. The diagnosis was made clinically and whenever required the laboratory support was taken.

We took data from $1^{\text {st }}$ Sept. 2011 to $31^{\text {st }}$ Aug. 2012. All the diagnosis was grouped into 15 categories. The diagnosis which does not fit into these categories was kept in "Other". The 15 categories include Acne, Alopecia Areata, Dermatophytosis, Drug reaction, Eczema, Leprosy, Lichen planus, Melasma, Psoriasis, Pyoderma, Scabies, STI, Urticaria, Viral infection and Vitiligo. Drug reaction include clinical pattern of cutaneous drug eruption.

The patients only from Rupandehi, Nawalparasi and Kapilvastu district were taken. The patients from other district and from India were excluded. The study population was grouped into four age group less than 15 years, 15 to 30 years, 31 to 45 years, and more than 45 years. Frequency of diseases according to months and gender were also recorded. MS-excel sheet was used to tabulate and analyze the data.

\section{RESULT}

There were 14926 patients in total. Among them 93.4\% (13943) were from Rupandehi, Nawal parasi and Kapilvastu districts only. Out of 13943, the patients from Rupandehi, Nawalparasi and Kapilvastu ditricts were 1244 6(89.3\%), 836 $(6.0 \%)$ and $661(4.7 \%)$ respectively.

The pattern of disease according to age group and gender in Rupandehi district is shown in Table 1 and Table 2. The maximum number of case was Dermatophytosis 2003 (16.1\%) followed by Eczema 1963 (15.8\%) and Acne 833 (6.7\%). The age group 15-30 years dominated. Acne was the most common dermatosis among this age group. Dermatophytosis was more common in male. The highest difference in distribution of disease was found in melasma with male: female ratio being more than 1: 5 . Vitiligo was the fourth common disease. In total female (50.4\%) outnumbered the male $(49.6 \%)$. 
Table 1: Pattern of disease according to age group in Rupandehi District

\begin{tabular}{|c|c|c|c|c|c|}
\hline \multicolumn{2}{|l|}{ Disease } & \multicolumn{2}{|c|}{ Age Group(years) } & \multicolumn{2}{|c|}{ Total } \\
\hline & $<15$ & $15-30$ & $31-45$ & $>45$ & \\
\hline Acne & 128 & 613 & 70 & 22 & $833(6.7 \%)$ \\
\hline Alopecia & 36 & 134 & 38 & 20 & $228(01.8 \%)$ \\
\hline Dermatophytosis & 289 & 833 & 485 & 396 & $2003(16.1 \%)$ \\
\hline Drug Reaction & 10 & 9 & 4 & 6 & $29(00.2 \%)$ \\
\hline Eczema & 333 & 622 & 496 & 512 & $1963(15.8 \%)$ \\
\hline Leprosy & 8 & 28 & 25 & 28 & $89(00.7 \%)$ \\
\hline Lichen planus & 13 & 34 & 27 & 47 & $121(01.0 \%)$ \\
\hline Melasma & 14 & 161 & 152 & 24 & $351(02.8 \%)$ \\
\hline Other & 896 & 1670 & 1046 & 1000 & $4612(37.0 \%)$ \\
\hline Psoriasis & 8 & 61 & 41 & 73 & $183(01.5 \%)$ \\
\hline Pyoderma & 112 & 99 & 80 & 73 & $364(02.9 \%)$ \\
\hline Scabies & 127 & 147 & 74 & 61 & $409(03.3 \%)$ \\
\hline STI & 3 & 20 & 08 & 17 & $48(00.4 \%)$ \\
\hline Urticaria & 46 & 147 & 132 & 96 & $421(03.4 \%)$ \\
\hline Viral infection & 47 & 74 & 31 & 88 & $240(01.9 \%)$ \\
\hline Vitiligo & 189 & 165 & 95 & 103 & $552(04.4 \%)$ \\
\hline Total & 2259 & 4817 & 2804 & 2566 & 12446 \\
\hline
\end{tabular}

Table 2: Distribution of disease by gender in Rupandehi district

\begin{tabular}{|l|c|c|c|}
\hline Disease & Male & Female & Total \\
\hline Acne & $331(2.7 \%)$ & $502(4.0 \%)$ & 833 \\
\hline Alopecia & $110(0.9 \%)$ & $118(0.9 \%)$ & 228 \\
\hline Dermatophytosis & $1170(9.4 \%)$ & $833(6.7 \%)$ & 2003 \\
\hline Drug Reaction & $17(0.1 \%)$ & $12(0.1 \%)$ & 29 \\
\hline Eczema & $978(7.9 \%)$ & $985(7.9 \%)$ & 1963 \\
\hline Leprosy & $71(0.6 \%)$ & $18(0.1 \%)$ & 89 \\
\hline Lichen planus & $65(0.5 \%)$ & $56(0.5 \%)$ & 121 \\
\hline Melasma & $58(0.5 \%)$ & $293(2.4 \%)$ & 351 \\
\hline Other & $2217(17.8 \%)$ & $2395(19.2 \%)$ & 4612 \\
\hline Psoriasis & $99(0.8 \%)$ & $84(0.7 \%)$ & 183 \\
\hline Pyoderma & $199(1.6 \%)$ & $165(1.3 \%)$ & 364 \\
\hline Scabies & $271(2.2 \%)$ & $138(1.1 \%)$ & 409 \\
\hline STI & $40(0.3 \%)$ & $8(0.06 \%)$ & 48 \\
\hline Urticaria & $147(1.2 \%)$ & $274(2.2 \%)$ & 421 \\
\hline Viral infection & $127(1.0 \%)$ & $113(0.9 \%)$ & 240 \\
\hline Vitiligo & $272(2.2 \%)$ & $280(2.2 \%)$ & 552 \\
\hline Total & $6172(49.6 \%)$ & $6274(50.4 \%)$ & 12446 \\
\hline
\end{tabular}

In Kapilvastu district (Table 3), Eczema was the most common dermatosis followed by Dermatophytosis 93(14\%) and Vitiligo 50 (7.6\%). Highest number of visits were made by the patients from 15-30 years of age group. Acne was the most common dermatosis $20(9.7 \%)$ in this group. Dermatophytosis and Eczema were more common in male, but vitiligo was more common in female (table 4). Melasma was more common in female.

Table 3: Pattern of disease according to age group in patients from Kapilvastu District

\begin{tabular}{|c|c|c|c|c|c|}
\hline Disease & & ge Group & ars) & & total \\
\hline & $<15$ & $15-30$ & $31-45$ & $>45$ & \\
\hline Acne & 3 & 20 & 1 & 0 & $24(3.7 \%)$ \\
\hline Alopecia & 0 & 2 & 1 & 0 & $3(0.5 \%)$ \\
\hline Dermatophytosis & 17 & 27 & 28 & 21 & $93(14 \%)$ \\
\hline Drug reaction & 0 & 2 & 1 & 0 & $3(0.4 \%)$ \\
\hline Eczema & 16 & 27 & 30 & 30 & $103(15.6 \%)$ \\
\hline Leprosy & 2 & 3 & 4 & 3 & $12(1.8 \%)$ \\
\hline Lichen planus & 0 & 1 & 1 & 4 & $6(0.9 \%)$ \\
\hline Melasma & 1 & 4 & 5 & 2 & $12(1.8 \%)$ \\
\hline Other & 47 & 81 & 68 & 77 & $273(41.3 \%)$ \\
\hline Psoriasis & 3 & 7 & 1 & 12 & $23(3.5 \%)$ \\
\hline Pyoderma & 2 & 1 & 3 & 2 & $8(1.2 \%)$ \\
\hline Scabies & 3 & 7 & 1 & 6 & $17(2.6 \%)$ \\
\hline STI & 0 & 4 & 3 & 3 & $10(1.5 \%)$ \\
\hline Urticaria & 2 & 2 & 8 & 2 & $14(2.1 \%)$ \\
\hline Viral infection & 0 & 4 & 1 & 5 & $10(1.5 \%)$ \\
\hline Vitiligo & 15 & $\overline{15}$ & 12 & 8 & $50(7.6 \%)$ \\
\hline Total & 111 & 207 & 168 & 175 & 661 \\
\hline
\end{tabular}

Table 4: Distribution of diagnosis by gender in patients from Nawalparasi and Kapilvastu districts

\begin{tabular}{|l|l|l|l|l|l|l|}
\hline \multirow{2}{*}{$\begin{array}{l}\text { District } \\
\text { Gender } \\
\text { diagnosis }\end{array}$} & \multicolumn{1}{|c|}{ Nawalparasi } & Female & Total & Male & Female & Total \\
\cline { 2 - 7 } Acne & $34(4.1 \%)$ & $31(3.7 \%)$ & 65 & $10(1.6 \%)$ & $14(2.1 \%)$ & 24 \\
\hline Alopecia & $9(1.1 \%)$ & $9(1.1 \%)$ & 18 & $3(0.5 \%)$ & $0(0 \%)$ & 3 \\
\hline Dermatohytosis & $82(9.8 \%)$ & $37(4.4 \%)$ & 119 & $60(9 \%)$ & $33(5 \%)$ & 93 \\
\hline Drug reaction & $3(0.4 \%)$ & $0(0.0 \%)$ & 3 & $2(0.3 \%)$ & $1(0.1 \%)$ & 3 \\
\hline Eczema & $80(9.6 \%)$ & $56(6.7 \%)$ & 136 & $63(9.6 \%)$ & $40(6 \%)$ & 103 \\
\hline Leprosy & $2(0.2 \%)$ & $1(0.2 \%)$ & 3 & $11(1.7 \%)$ & $1(0.1 \%)$ & 12 \\
\hline Lichen planus & $4(0.5 \%)$ & $5(0.6 \%)$ & 9 & $4(0.6 \%)$ & $2(0.3 \%)$ & 6 \\
\hline Melasma & $9(1.1 \%)$ & $27(3.2 \%)$ & 36 & $4(0.6 \%)$ & $8(1.2 \%)$ & 12 \\
\hline Other & $153(18.3 \%)$ & $134(16.0 \%)$ & 287 & $144(21.8 \%)$ & $129(19.5 \%)$ & 273 \\
\hline Psoriasis & $9(1.1 \%)$ & $7(0.8 \%)$ & 16 & $16(2.4 \%)$ & $7(1.1 \%)$ & 23 \\
\hline Pyoderma & $13(1.5 \%)$ & $15(1.8 \%)$ & 28 & $4(0.6 \%)$ & $4(0.6 \%)$ & 8 \\
\hline Scabies & $22(2.6 \%)$ & $9(1.1 \%)$ & 31 & $14(2.1 \%)$ & $3(0.5 \%)$ & 17 \\
\hline STI & $4(0.5 \%)$ & $2(0.2 \%)$ & 6 & $6(0.9 \%)$ & $4(0.6 \%)$ & 10 \\
\hline Urticaria & $12(1.4 \%)$ & $16(1.9 \%)$ & 28 & $2(0.3 \%)$ & $12(1.8 \%)$ & 14 \\
\hline Vitiligo & $17(2 \%)$ & $26(3.1 \%)$ & 43 & $12(1.9 \%)$ & $38(5.7 \%)$ & 50 \\
\hline Viral infection & $4(0.5 \%)$ & $4(0.5 \%)$ & 8 & $6(0.9 \%)$ & $4(0.6 \%)$ & 10 \\
\hline Total & $457(54.7 \%)$ & $379(45.3 \%)$ & 836 & $361(54.6 \%)$ & $300(45.4 \%)$ & 661 \\
\hline
\end{tabular}


In Nawalparasi district (Table 5) Eczema was the most commonly presented dermatosis $136(16.3 \%)$ followed by Dermatophytosis 119 (14.2\%) and Acne 65 (7.8\%). Vitiligo was the fourth common dermatosis. Among age group the highest number of visit was made by 15-30 years patients. Acne was the most common in this age group. Eczema, dermatophytosis and acne were found more common in male than with female (Table 4). Melasma and vitiligo was more common in female.

Table 5: Pattern of disease according to age group in patients from Nawalparasi district

\begin{tabular}{|c|c|c|c|c|c|}
\hline \multirow[t]{2}{*}{ Disease } & \multicolumn{4}{|c|}{ Age group(years) } & \multirow[t]{2}{*}{ Total } \\
\hline & $<15$ & $15-30$ & $31-45$ & $>45$ & \\
\hline Acne & 7 & 54 & 4 & 0 & $65(7.8 \%)$ \\
\hline Alopecia & 1 & 9 & 5 & 3 & $18(2.2 \%)$ \\
\hline Dermatophytosis & 17 & 50 & 23 & 29 & $119(2.2 \%)$ \\
\hline Drug reaction & 0 & 0 & 2 & 1 & $3(0.4 \%)$ \\
\hline Eczema & 16 & 32 & 36 & 52 & $136(16.3 \%)$ \\
\hline Leprosy & 0 & 2 & 0 & 1 & $3(0.4 \%)$ \\
\hline Lichen planus & 2 & 4 & 2 & 1 & $9(1.1 \%)$ \\
\hline Melasma & 2 & 12 & 18 & 4 & $36(4.3 \%)$ \\
\hline Other & 31 & 113 & 67 & 76 & $287(34.35 \%)$ \\
\hline Psoriasis & 3 & 3 & 2 & 8 & $16(1.9 \%)$ \\
\hline Pyoderma & 4 & 13 & 5 & 6 & $28(3.3 \%)$ \\
\hline Scabies & 6 & 15 & 5 & 5 & $31(3.7 \%)$ \\
\hline STI & 0 & 1 & 3 & 2 & $6(0.7 \%)$ \\
\hline Urticaria & 4 & 14 & 6 & 4 & $28(3.3 \%)$ \\
\hline Viral infection & 0 & 6 & 0 & 2 & $8(1.0 \%)$ \\
\hline Vitiligo & 9 & 14 & 10 & 10 & $43(5.1 \%)$ \\
\hline Total & 102 & 342 & 188 & 204 & 836 \\
\hline
\end{tabular}

Figure I: Monthly trend of the three common disease in patients from Rupandehi

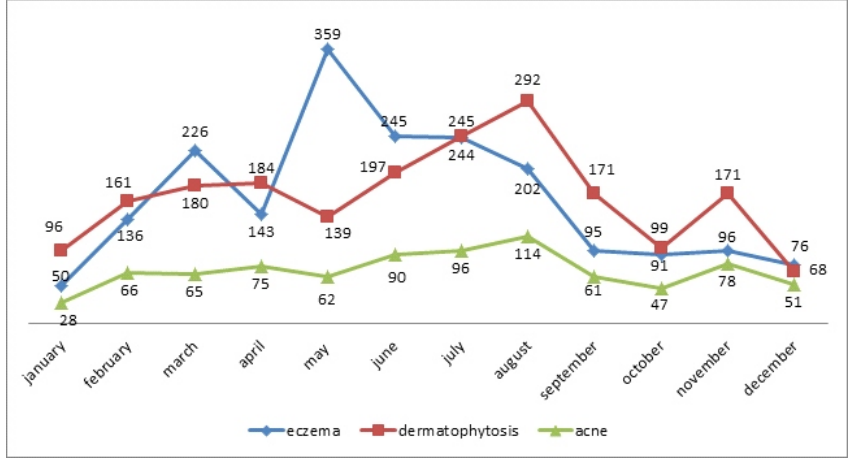

Figure II: Monthly trend of three common disease in patients from Kapilvastu

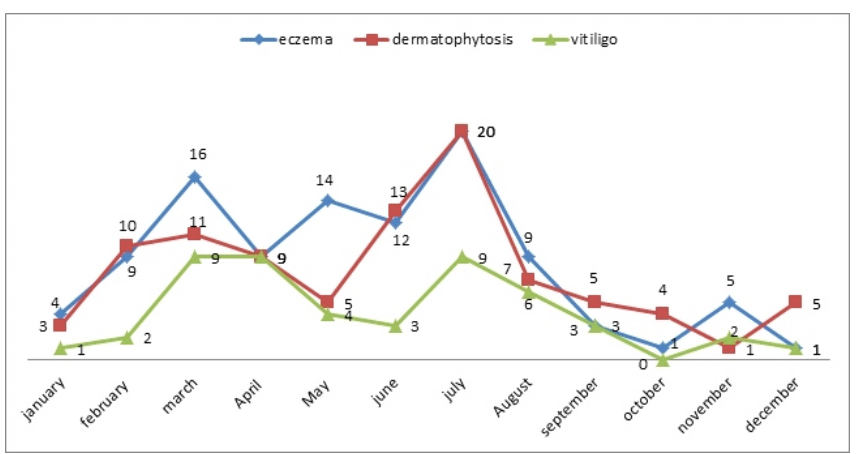

Figure III: Monthly trend of three common dermatosis in patients from Nawalparasi.

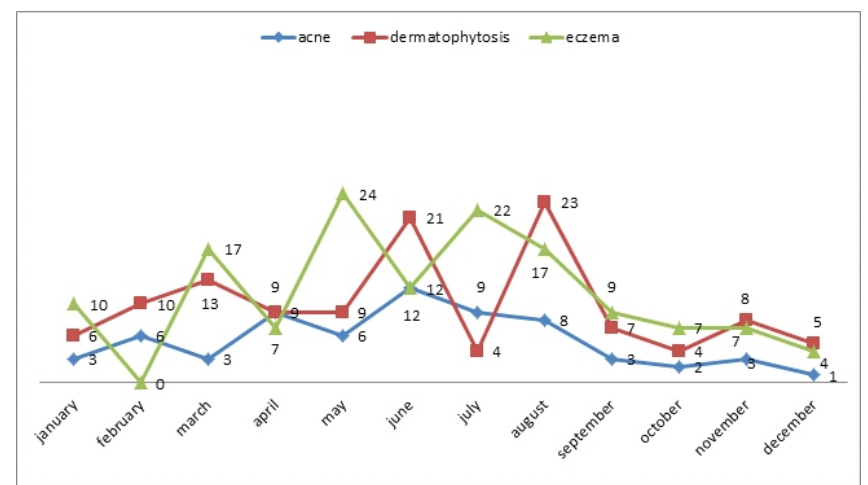

When monthly trend of three common dermatosis in each district were seen, highest number of eczema was recorded in month of May in Rupandehi and Nawalparasi and July in Kapilvastu district. Highest number of dermatophytosis was recorded in August in Rupandehi and Nawalparasi district and at July in Kapilvastu district.(Figure I, II, III)

\section{DISCUSSION}

The study shows the pattern of skin diseases in Rupandehi, Kapilvastu and Nawalparasi districts of Nepal. Number of patients from Rupandehi was significantly high in comparision to that of Kapilvastu and Nawalparasi district. Since the study was done from the secondary data, the researcher's effort in this regard was limited. The community research can avoid this problem.

Dermatophytosis was commonest in Rupandehi district. The study by SL Walker in terai region of Nepal showed the fungal infection to be the commonest. ${ }^{6}$ The study conducted in mountain area showed fungal infection to be the fourth 
common dermatosis. ${ }^{4}$ Our study showed similarity showing fungal infection is commonest in Terai. The number of patient taken from Kapilvastu and Nawalparasi were very less in comparision to Rupandehi district, but Dermatophytosis was still second in number after Eczema.

This reflects the fact that warm and humid climate creates the environment for the development of fungal infection. ${ }^{8}$

As in other studies Eczema was also common being second in number in Rupandehi district and first in number in Kapilvastu and Nawalparasi district. ${ }^{4,6,9}$

The most common age group presenting to the OPD was 15-30 years. This shows similarity with the study done by Karn D et al. who also opined that this may be due to the fact that this is most active population and the people in this age group are also self conscious about their looks, skin and personalities.

When monthly trend of the dermatosis was analysed, it was seen that there was increasing trend in number of dermatosis in summer season in comparision to that in winter. This can be attributed to UVR exposure which is known to suppress cutaneous cell mediated immunity in human, contributing to skin aging process as well as development of photoeczema. ${ }^{10}$

Study by Jha AK showed the increasing trend of fungal infection insummer season. In our study in all three districts, dermatophytosis number increases in summer season and gradually decline in winter season. ${ }^{11}$

Dermatophytosis and Eczema were seen more common in male than in female. Studies have shown more prevalence of dermatophytosis in male compared to female. Progesterone has been shown to prevent dermatophyte multiplication in vitro. Males may be more vulnerable to infection due to the higher exposures in the army, school and sporting activities and due to the types of shoes and socks used. ${ }^{12,13,14}$

Vitiligo is more common in female in this study. Most series based on outpatient attendance shows vitiligo to be more common in female, but the frequency in population is probably the same in same sexes. ${ }^{15}$ This study may have reflected this fact.

\section{CONCLUSION}

Dermatophytosis and eczema are commonest dermatoses in
Terai region. The patient from age group 15-30 years were the most frequent visitor in dermatology OPD. The common dermatoses show seasonal trend with frequency increasing in summer. Dermatophytosis is more common in male.

\section{ACKNOWLEDGEMENT}

We want to thank Dr. Rajan B. Tajhya and Dr. Pratistha Shrestha ( $2^{\text {nd }}$ and $3^{\text {rd }}$ batch PG residents, UCMS); Dr. Jagat Bandhu Mahat, Dr. Rabin Ghimire, Dr. Rana Bahadur Bogati ( $9^{\text {th }}$ batch MBBS, UCMS); Mr. Shankar Prasad Joshi (Medical Record Officer, UCMS) for their contribution in this research.

\section{REFERENCES}

1. Grills N, Grills C, Spelman T, Stoove M, Hellard M, El-Hayek C, Singh R. Prevalence Survey of dermatological conditions in mountainous north India. Int J Dermatol 2012;51:579-87. http://dx.doi.org/10.1111/j.1365-4632.2011.05131.x PMid: 22515583

2. Annual Report. Kathmandu: Government of Nepal/ Minstry of health and population;2012.p145

3. Memon KN, Soomro RA, Ansari MS. Pattern of skin diseases in patients visiting a tertiary care health facility at Hyderabad, Pakistan. JAyub med coll 2011;23(4):37-9.

4. Shrestha DP, Gurung D, Rosdahl I. Prevalence of skin diseases and impact on quality of life in Hilly region of Nepal. JIOM 2012;34:44-9.

5. Karn D, Khatri R, Timalsina M. Prevalence of skin disease in Kavre district, Nepal. NJDVL 2010;9(1):7-9

6. Walker SL, Shah M, Hubbard VG, Pradhan HM, Ghimire M. skin disease is common in rural Nepal: result of point prevalence study. B J Dermatol 2008;158:334-8. PMid:17711533

7. Gangadharan C, Joseph A, Sarajini PA. Pattern of skin disease in Kerala. IJDVL 1976;42(1):49-51.

8. Hay RJ, Moore MK. Mycology. In: Burns T, Breathnach S, Cox $N$, Griffiths C, editors. Rook's textbook of dermatology. 7th ed. Oxford: Blackwell Science Ltd; 2004:p. 31.23 http://dx.doi.org /10.1002/9780470750520.ch31

9. Gutierrez EL, Galarza C, Ramos W, Mendoza M, Smith ME, Ortega-Loayza AG. Influene of climatic factors on the medical attentions of dermatologic diseases in hospital of Lima, Peru. An Bras Dermatol 2010;85(4):461-8. http://dx.doi.org/10.1590/ S0365-05962010000400007 PMid:20944906 
10. Walker SL, Hawk JLM, Young AR. Acute and chronic effects of ultraviolet radiation on skin. In: Freedberg IM, Eisen AZ, Wolff K, Austen KF, Goldsmith LA, Katz SI, editors. Fitzpatrick's dermatology in general medicine. 6th ed. New York: Mc. Graw Hill; 2003: p. 1275-81

11. Jha AK, Gurung D. Seasonal variation of skin diseases in Nepal: A hospital based annual study of outpatient visit. $N$ Med Col J 2006;8(4):266-8.

12. Kamothi MN, Patel BP, Mehta SJ, Kikani KM, Pandya JM. Prevalence of dermatophyte infection in district Rajkot. Electronic Journal of Pharmacology and Therapy 2010;3:1-3.
13. Jain N, Sharma M, Saxena VN. Clinico-mycological profile of dermatophytosis in Jaipur, Rajasthan. Ind $J$ dermatol Ven lep 2008;74(3):274-5. http://dx.doi.org/10.4103/0378-6323.41388

14. Qadim HH, Golforoushan F, Azimi H, Goldust M. Factors leading to dermatophytosis. Ann Parasitol 2013;59(2):99-102. PMid:2417130415.

15. Howitz J, Brodthagen H, Schwartz Met al. Prevalence of vitiligo. Arch Dermatol 1977;113:47-52. http://dx.doi.org/10.1001/ archderm. 113.1.47 http://dx.doi.org/10.1001/ archderm. 1977. 01640010049006 PMid:831622 